This document was prepared in conjunction with work accomplished under Contract No. DE-AC09-96SR18500 with the U. S. Department of Energy.

\title{
DISCLAIMER
}

This report was prepared as an account of work sponsored by an agency of the United States Government. Neither the United States Government nor any agency thereof, nor any of their employees, nor any of their contractors, subcontractors or their employees, makes any warranty, express or implied, or assumes any legal liability or responsibility for the accuracy, completeness, or any third party's use or the results of such use of any information, apparatus, product, or process disclosed, or represents that its use would not infringe privately owned rights. Reference herein to any specific commercial product, process, or service by trade name, trademark, manufacturer, or otherwise, does not necessarily constitute or imply its endorsement, recommendation, or favoring by the United States Government or any agency thereof or its contractors or subcontractors. The views and opinions of authors expressed herein do not necessarily state or reflect those of the United States Government or any agency thereof. 


\section{INITIAL SB4 MELT RATE FURNACE TESTING (U)}

M. E. Smith

D. H. Miller

July 2005

Immobilization Technology Section Savannah River National Laboratory

Aiken, SC 29808

Prepared for the U.S. Department of Energy Under Contract Number DEAC09-96SR18500

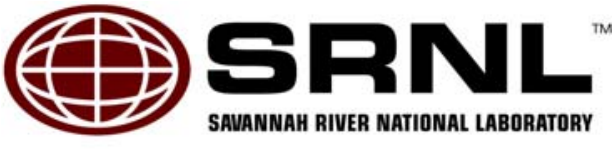

We Put Science To Work 


\title{
DISCLAIMER
}

This report was prepared by Westinghouse Savannah River Company (WSRC) for the United States Department of Energy under Contract No. DE-AC09-96SR18500 and is an account of work performed under that contract. Neither the United States Department of Energy, nor WSRC, nor any of their employees makes any warranty, expressed or implied, or assumes any legal liability or responsibility for the accuracy, completeness, or usefulness, of any information, apparatus, or product or process disclosed herein or represents that its use will not infringe privately owned rights. Reference herein to any specific commercial product, process, or service by trademark, name, manufacturer or otherwise does not necessarily constitute or imply endorsement, recommendation, or favoring of same by WSRC or by the United States Government or any agency thereof. The views and opinions of the authors expressed herein do not necessarily state or reflect those of the United States Government or any agency thereof.

\author{
Printed in the United States of America \\ Prepared For \\ U.S. Department of Energy
}


Key Words: Melt rate, SB4, DWPF, glass

Retention: Permanent

\section{INITIAL SB4 MELT RATE FURNACE TESTING (U)}

M. E. Smith

D. H. Miller

July 2005

Immobilization Technology Section Savannah River National Laboratory Aiken, SC 29808

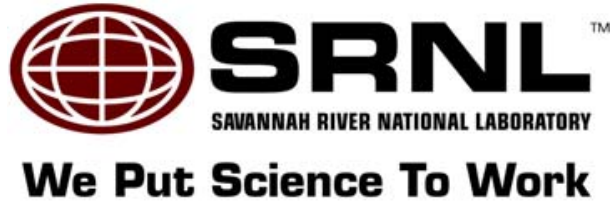




\section{REVIEWS AND APPROVALS}

\section{AUTHORS:}
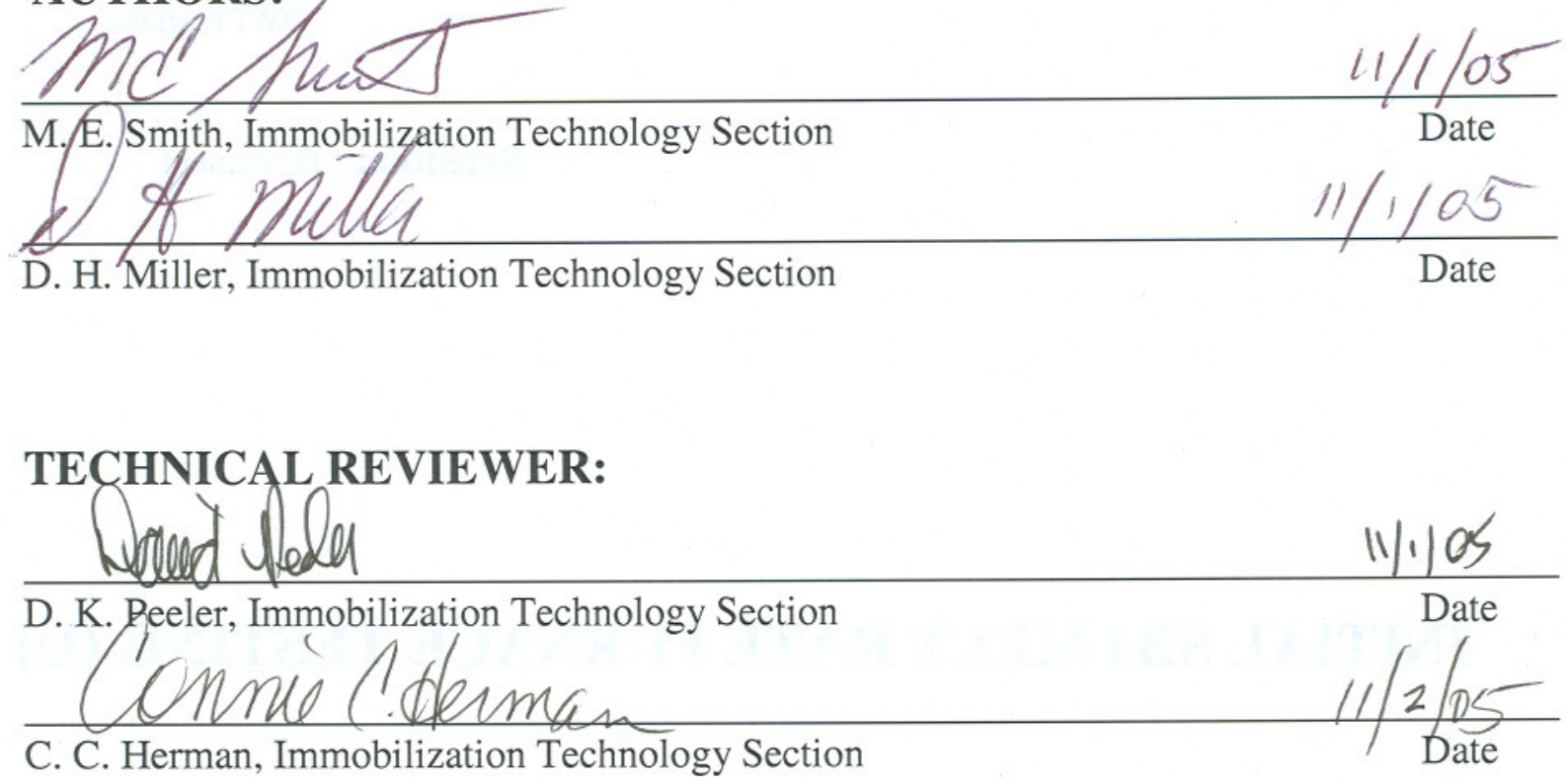

\section{APPROVERS}

PREdnars $11 / 7 / 05$

R. E. Edwards, Manager, Immobilization Technology Section Date Shavon frhaus $11 / 2 / 05$ S. L. Marra, Manager, Glass Formulation \& Process Development Date

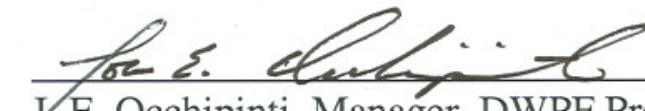
$11-10.05$

J. E. Occhipinti, Manager, DWPF Process Engineering

Date 


\section{EXECUTIVE SUMMARY}

The Defense Waste Processing Facility (DWPF) is presently vitrifying Sludge Batch 3 (SB3) and preparing to process Sludge Batch 4 (SB4) in late 2006 or early 2007. The final composition of SB4 has not been finalized, as various blending and/or washing strategies are still being considered. SB4 will be comprised of the contents of Tanks 5, 6, 7, 8, and 11 (which will be transferred to Tank 51) along with plutonium and neptunium solutions from $\mathrm{F}$ and $\mathrm{H}$ Canyons, and possibly material from Tank $4{ }^{1}$ Tank 4 was originally included in projections, but plans have since changed (after completion of these tests) and Tank 4 is no longer part of SB4 due to problems with sludge removal. Even though the final SB4 composition was not finalized at the time of this study, there were 20 bounding options documented ${ }^{2}$ that could be used for preliminary melt rate tests. At the time of these tests, the SB4 compositions described as "SB4 1200 canister baseline" and "SB4 1200 canister baseline (one less washed)" documented elsewhere ${ }^{3}$ were chosen for these tests. The 1200 canister describes the number of equivalent canisters that would be produced from the beginning of the current contract period before SB3 is blended with SB4. These compositions were chosen as they had the highest amount of SB4 in the blend and were therefore considered as worse case SB4 feeds with regards to melt rate. This is because SB4 has higher alumina levels of any sludge batch yet processed and alumina has a negative impact on the DWPF melt rate. This baseline sludge includes Tank 4 but does not include auxiliary waste streams such as the Actinide Removal Process (ARP) stream, which contains monosodium titanate (MST), entrained sludge, and various soluble sodium compounds as the result of filter cleaning and stream adjustment for transfer.

These preliminary dry-fed Melt Rate Furnace (MRF) tests were needed to initially evaluate melt rate/waste throughput. This study addressed SB4 with Frits 418 and 320, the impact of waste loading, the impact of the higher amount of Al in SB4, the amount of sludge washing, the possible addition of the ARP stream, the possible need to use a new frit to increase sulfur solubility, and the impact of the use of low $\mathrm{Li}$ frits to minimize the formation of an Al-Li-silicate phase that may be an intermediate reaction phase that could possibly hinder melt rate for SB4. For the SB4 sludge tested in the MRF for this preliminary work, the melt rate for SB4 simulant was lower than SB3. The higher alumina content in SB4 is probably the reason for the lower SB4 melt rate. Because the actual SB4 composition has not yet been finalized and may be different enough from the simulant SB4 sludges tested for these tests, the actual difference in melt rate for the two sludge batches cannot be projected. Therefore, further melt rate testing, including slurry testing in the Slurry-Fed Melt Rate Furnace (SMRF) will be needed as the SB4 compositions are further refined.

Tests were performed with non-radioactive, simulated SB4 material. Due to the small-scale of the test equipment and the design of the equipment, as well as the use of dry, non-radioactive simulant feed, the behavior of the actual radioactive SB4 feed in the DWPF melter cannot be fully proven. 


\section{TABLE OF CONTENTS}

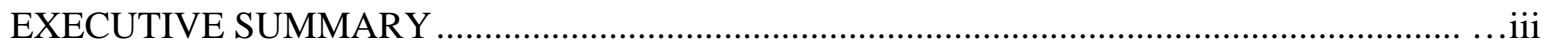

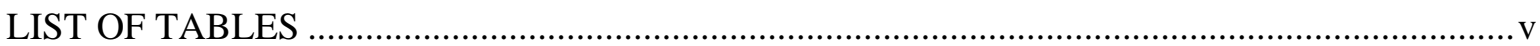

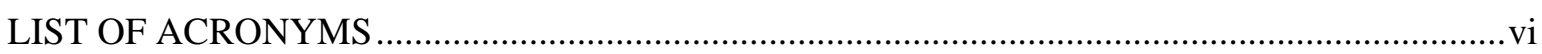

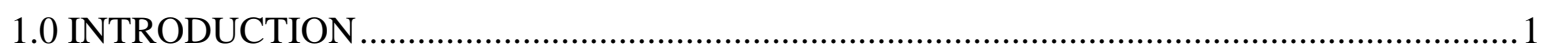

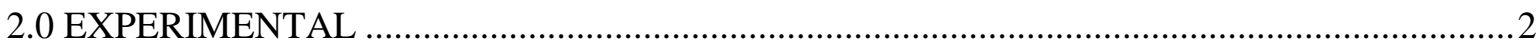

2.1 4-L SRAT and 22-L SRAT/SME Feed Preparation Details..............................................2

2.2 MRF SB4 Testing Details....................................................... 4

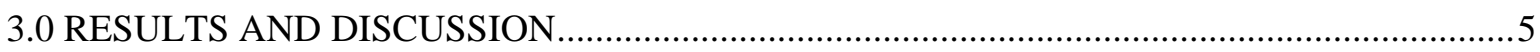

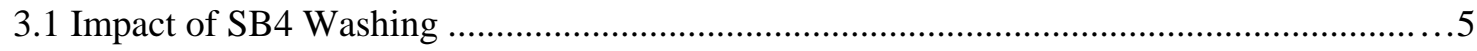

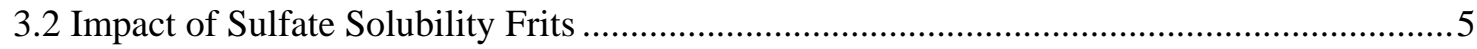

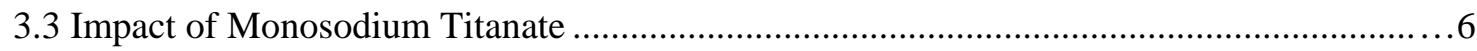

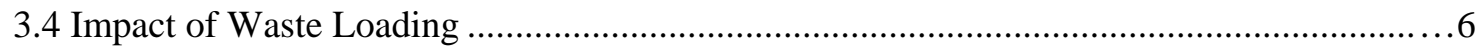

3.5 Impact of Low Lithia Frits ........................................................................................

3.6 Impact of Higher Levels of Sodium in the Sludge ..........................................................

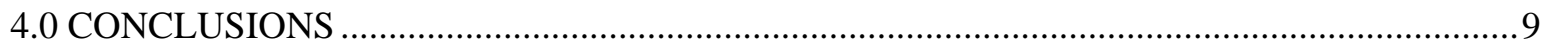

5.0 RECOMMENDATIONS/PATH FORWARD..........................................

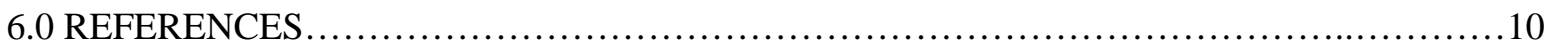




\section{LIST OF TABLES}

Table 2-1. Target 1200 Canister SB4 Baseline and SB4 Baseline One Less Washed Simulants, and Typical SB3 Simulant Sludge Compositions (Weight \% Calcined Solids) ................

Table 2-2. Descriptions of SRAT Runs for SB4 MRF Tests......................................

Table 2-3. SB4 Sludge Simulant Analyzed Compositions (Weight \% Calcined Solids) ................4

Table 3-1. MRF Melt Rate (LMR) Results for Impact of SB4 Washing Tests (35\% WL)..............5

Table 3-2. Target and Measured Compositions of SB4 Sulfate Solubility Frits and Frit 320............6

Table 3-3. MRF Melt Rates (LMR) for SB4 Sulfate Solubility Frits and Frit 320...................6

Table 3-4. Impact of Waste Loading (WL) on SB4 Baseline MRF Melt Rate (LMR).................7

Table 3-5. Target and Measured Compositions of Low Lithia Frits and Frit 320....................7

Table 3-6. MRF Melt Rates (LMR) for Low Lithia Frits.......................................

Table 3-7. MRF Melt Rates (LMR) for the Higher Levels of Sodium in the SB4 Sludge...............8 


\section{LIST OF ACRONYMS}

$\begin{array}{ll}\text { ARP } & \text { Actinide Removal Process } \\ \text { CBU } & \text { Closure Business Unit } \\ \text { DWPF } & \text { Defense Waste Processing Facility } \\ \text { LMR } & \text { Linear Melt Rate } \\ \text { MRF } & \text { Melt Rate Furnace } \\ \text { REDOX } & \text { REDuction/OXidation } \\ \text { SB3 } & \text { Sludge Batch 3 } \\ \text { SB4 } & \text { Sludge Batch 4 } \\ \text { MST } & \text { Monosodium Titanate } \\ \text { SMRF } & \text { Slurry-Fed Melt Rate Furnace } \\ \text { SRAT } & \text { Sludge Receipt and Adjustment Tank } \\ \text { SRNL } & \text { Savannah River National Laboratory } \\ \text { TTR } & \text { Task Technical Request } \\ \text { WSRC } & \text { Westinghouse Savannah River Company }\end{array}$




\subsection{INTRODUCTION}

The Defense Waste Processing Facility (DWPF) is presently vitrifying Sludge Batch 3 (SB3) and preparing to process Sludge Batch 4 (SB4) in late 2006 or early 2007. The final composition of SB4 has not been finalized, as various blending and/or washing strategies are still being considered. SB4 will be comprised of the contents of Tanks 5, 6, 7, 8, and 11 (which will be transferred to Tank 51) along with plutonium and neptunium solutions from $\mathrm{F}$ and $\mathrm{H}$ Canyons, and possibly material from Tank $4 .^{1}$ Tank 4 was originally included in projections, but plans have since changed (after completion of these tests) and Tank 4 is no longer part of SB4 due to problems with sludge removal. Even though the final SB4 composition was not finalized at the time of this study, there were 20 bounding options provided elsewhere ${ }^{2}$ that could be used for preliminary melt rate tests. At the time of these tests, the SB4 compositions described as "SB4 1200 canister baseline" and "SB4 1200 canister baseline (one less washed)" documented elsewhere ${ }^{3}$ were chosen for these tests. The 1200 canister describes the number of equivalent canisters that would be produced from the beginning of the current contract period before SB3 is blended with SB4. These compositions were chosen as they had the highest amount of SB4 in the blend and were therefore considered as worse case SB4 feeds with regards to melt rate. This is because SB4 has higher alumina levels of any sludge batch yet processed and alumina has a negative impact on the DWPF melt rate. This baseline sludge includes Tank 4 but does not include auxiliary waste streams such as the Actinide Removal Process (ARP) stream, which contains monosodium titanate (MST), entrained sludge, and various soluble sodium compounds as the result of filter cleaning and stream adjustment for transfer.

These dry-fed Melt Rate Furnace (MRF) initial melt rate tests were needed to provide a preliminary assessment of melt rate for SB4 and address the following questions.

- What is the relative SB4 melt rate (using either Frit 418 or Frit 320) when compared to SB3 given the high projected amounts of alumina in SB4?

- What is the impact of washing of SB4 on melt rate?

- What is the impact of the ARP stream (specifically MST) on melt rate?

- Due to the high projected levels of sulfate in SB4 and the possible need to use frits that increase sulfate solubility, what is the impact of these frits on SB4 melt rate (sulfate solubility testing documented elsewhere $\left.{ }^{4}\right)$ ?

- What is the general impact of waste loading on SB4 melt rate using Frit 320?

- Due to the possibility of forming a problematic Al-Li-silicate intermediate phase that could impede SB4 melt rate, what is the impact of using low Li frits with SB4?

- Due to the fact that the SB4 sludge simulant was lower in sodium than the SB4 projections (an acceptable method for including soluble sodium has not been determined for sludge simulants), what is the impact of somewhat higher (and therefore closer to projected levels) SB4 sludge simulant sodium levels on melt rate?

The work was performed per Task Technical and Quality Assurance Plan WSRC-RP-2004-00713. ${ }^{5}$ Tests were performed with non-radioactive, simulated SB4 material. Due to the small-scale of the test equipment and the design of the equipment, as well as the use of dry, non-radioactive simulant feed, the behavior of the actual radioactive SB4 feed in the DWPF melter cannot be fully proven. However, previous SRNL melt rate results have shown trends that are consistent. 
WSRC-TR-2005-00339

\subsection{EXPERIMENTAL}

A series of MRF tests were run with simulated SB4 sludge SRAT product and various frits. The following is a description of the various tests. All tests used SB4 baseline sludge except for the "impact of sludge washing" (used both SB4 baseline and SB4 one less washed sludges). All tests except for the "impact of waste loading” series were run at $35 \%$ waste loading.

- Impact of SB4 Sludge Washing - Compared melt rates of SB4 baseline and one less washed sludges (as defined earlier in this report) when mixed with either Frit 320 or Frit 418. This data was also to be used to compare the relative melt rate of SB4 when compared to previous MRF tests with SB3 at the same 35\% waste loading and using the same two frits.

- Impact of Sulfate Solubility Frits - The cited sulfate level for SB4 at the time of testing raised concerns that there could be a glass sulfate solubility issue for SB4 when using either Frit 320 or Frit 418. Therefore a series of frits were designed to increase the sulfate solubility of the glass (frits had $\mathrm{CaO}, \mathrm{V}_{2} \mathrm{O}_{5}$, or a combination of the two oxides). Given the positive impact on increasing sulfate solubility, ${ }^{4}$ the purpose of the test was to determine if SB4 melt rate was negatively impacted by these alternative frits.

- Impact of Monosodium Titanate (MST) - There is the possibility that MST from ARP will be added at some point when DWPF is processing SB4. The purpose of these tests was to determine the impact of the MST stream on SB4 melt rate. The tests were performed by adding MST to target $1 \%$ and $2 \% \mathrm{TiO}_{2}$ in the final glass composition. Frit 320 was used for these tests.

- Impact of Waste Loading - Due to the desire to have a SB4 glass product with a high waste loading, a series of MRF tests were run with SB4 SRAT product and Frit 320 at waste loadings from 20 to $43 \%$.

- Impact of Low Lithia Frits - SB4 will have a significantly higher level of Al as compared to previous sludge batches processed in DWPF. The use of low Li frits is being considered to minimize the formation of an intermediate Al-Li-silicate phase that could lower melt rate based on thermodynamic modeling. The purpose of these tests was to determine the impact of these low Li frits on SB4 melt rate. It was realized that the use of low Li frits could make the determination of the waste loading of DWPF feeds via the Li concentration method difficult to perform.

- Impact of SB4 Na levels - Due to the inability to add insoluble sodium to make the SB4 simulant, the sodium level in the targeted SB4 sludge simulant was lower than the projected sodium level given elsewhere. ${ }^{2}$ Since sodium has historically had a positive benefit on melt rate, additional sodium (in the form of sodium formate and nitrate) was added to SB4 SRAT product to achieve the full Closure Business Unit (CBU) projected SB4 sodium amount (16.2\%) and an amount midway between the analyzed SB4 simulant sodium level (11.2 \% even though recipe target was $9.34 \%$ ) and the full CBU projection. The purpose of this test was to see if these higher sodium levels would positively impact melt rate.

\subsection{4-L SRAT and 22-L SRAT Feed Preparation Details}

At the time of these tests, the SB4 compositions described as "SB4 1200 canister baseline" and "SB4 1200 canister baseline (one less washed)" as documented elsewhere ${ }^{3}$ were chosen as they were considered worst case with regards to melt rate due to their high alumina content. The 1200 canister describes the number of equivalent canisters that would be produced from the beginning of the current contract period before SB3 is blended with SB4. This baseline sludge includes Tank 4 but does not include auxiliary waste streams such as the ARP stream, which contains MST, entrained sludge, and various soluble sodium compounds as the result of filter cleaning and stream adjustment for transfer.

The initial SB4 melt rate test Sludge Receipt and Adjustment Tank (SRAT) products were made using the above described sludge compositions (either baseline or one less washed) and the same feed preparation process strategy (130\% acid stoichiometry, 0.2 REDuction/Oxidation (REDOX) defined as 
$\mathrm{Fe}^{2+} / \mathrm{Fe}^{\text {total }}$ ). Unless multiple waste loadings were tested, the targeted waste loading was always 35\%. Table 2-1 gives the targeted SB4 baseline and SB4 one less washed sludge simulant compositions used for these tests. A typical SB3 simulant sludge composition is given for comparison as well. The SB4 compositions are very similar (within analytical error), even with regards to sodium. The main differences between the SB4 and SB3 sludge compositions are the higher levels of Al and lower levels of Fe in the SB4 sludges. The difference in the levels of both of these elements would indicate slower melt rates for SB4 relative to SB3.

Table 2-1. Target 1200 Canister SB4 Baseline and SB4 Baseline One Less Washed Simulants, and Typical SB3 Simulant Sludge Compositions (Weight \% Calcined Solids)

\begin{tabular}{||c|c|c|c||}
\hline \hline ELEMENT & SB4 BASELINE & $\begin{array}{c}\text { SB4 BASELINE (ONE } \\
\text { LESS WASHED) }\end{array}$ & TYPICAL SB3 $^{9}$ \\
\hline $\mathrm{Al}$ & 15.23 & 15.00 & 9.57 \\
\hline $\mathrm{Ba}$ & 0.18 & 0.17 & 0.14 \\
\hline $\mathrm{Ca}$ & 1.89 & 1.86 & 2.37 \\
\hline $\mathrm{Cr}$ & 0.21 & 0.21 & 0.15 \\
\hline $\mathrm{Cu}$ & 0.08 & 0.08 & 0.16 \\
\hline $\mathrm{Fe}$ & 20.49 & 20.18 & 28.35 \\
\hline $\mathrm{K}$ & 1.17 & 1.15 & 0.12 \\
\hline $\mathrm{Mg}$ & 1.15 & 1.13 & 2.15 \\
\hline $\mathrm{Mn}$ & 6.37 & 6.27 & 4.07 \\
\hline $\mathrm{Na}$ & 13.68 & 14.59 & 14.05 \\
\hline $\mathrm{Ni}$ & 3.84 & 3.78 & 1.06 \\
\hline $\mathrm{Pb}$ & 0.08 & 0.08 & 0.01 \\
\hline $\mathrm{Si}$ & 1.47 & 1.45 & 1.04 \\
\hline $\mathrm{Zn}$ & 0.12 & 0.11 & 0.32 \\
\hline $\mathrm{Zr}$ & 0.33 & 0.32 & 0.49 \\
\hline \hline
\end{tabular}

A total of 4 SRAT runs were performed to make SRAT product for these initial SB4 MRF tests. The SB4 SRAT runs and feed sludge ID numbers are listed below in Table 2-2. Table 2-3 gives the analyzed elemental compositions for the sludge simulants used for each of the SRAT runs. Additional details of the 4-L SB4-3 and SB4-4 runs are given elsewhere. ${ }^{6}$ Further details for the two 22-L SRAT runs (SB4-9 and SB4-12), are documented as well. ${ }^{7}$ These reports can be reviewed for any discussions on differences of the targeted versus analyzed sludge compositions.

Table 2-2. Descriptions of SRAT Runs for SB4 MRF Tests

\begin{tabular}{||c|c|c|c||}
\hline \hline SRAT RUN ID & SRAT DESCRIPTION & VESSEL SIZE & FEED SLUDGE ID \\
\hline SB4-3 & SB4 Baseline & $4-\mathrm{L}$ & SB4-1 (011304-1) \\
\hline SB4-4 & SB4 Baseline (one less wash) & 4-L & SB4-2 (011304-2) \\
\hline SB4-9 & SB4 Baseline & 22-L & SB4-5 (020705) \\
\hline SB4-12 & SB4 Baseline & 22-L & 031505 \\
\hline
\end{tabular}


Table 2-3. SB4 Sludge Simulant Analyzed Compositions (Weight \% Calcined Solids)

\begin{tabular}{||c|c|c|c|c||}
\hline $\begin{array}{c}\text { SLUDGE FEED } \\
\text { ID }\end{array}$ & $\begin{array}{c}\text { SB4-1 } \\
(01130401)\end{array}$ & $\begin{array}{c}\text { SB4-2 } \\
(011304-2)\end{array}$ & $\begin{array}{c}\text { SB4-5 } \\
(020705)\end{array}$ & 031505 \\
\hline SRAT RUN ID & SB4-3 & SB4-4 & SB4-9 & SB4-12 \\
\hline $\mathrm{Al}$ & 14.4 & 14.1 & 14.5 & 14.8 \\
\hline $\mathrm{Ba}$ & 0.179 & 0.171 & 0.178 & 0.174 \\
\hline $\mathrm{Ca}$ & 2.02 & 1.97 & 2.23 & 2.28 \\
\hline $\mathrm{Cr}$ & 0.163 & 0.172 & 0.131 & 0.164 \\
\hline $\mathrm{Cu}$ & 0.079 & 0.080 & 0.066 & 0.076 \\
\hline $\mathrm{Fe}$ & 22.9 & 22.3 & 22.5 & 22.9 \\
\hline $\mathrm{K}$ & 0.873 & 0.902 & 0.818 & 0.99 \\
\hline $\mathrm{Mg}$ & 1.07 & 1.07 & 0.886 & 1.02 \\
\hline $\mathrm{Mn}$ & 5.95 & 5.83 & 5.96 & 6.12 \\
\hline $\mathrm{Na}$ & 12.2 & 12.5 & 11.9 & 11.2 \\
\hline $\mathrm{Ni}$ & 3.29 & 3.11 & 3.21 & 3.28 \\
\hline $\mathrm{P}$ & 0.030 & 0.030 & 0.045 & 0.038 \\
\hline $\mathrm{Pb}$ & 0.017 & 0.020 & $<0.010$ & 0.021 \\
\hline $\mathrm{S}$ & 0.295 & 0.300 & 0.281 & 0.267 \\
\hline $\mathrm{Si}$ & 1.46 & 1.46 & 1.47 & 1.41 \\
\hline $\mathrm{Ti}$ & 0.022 & 0.022 & 0.024 & 0.023 \\
\hline $\mathrm{Zn}$ & 0.125 & 0.128 & 0.104 & 0.124 \\
\hline $\mathrm{Zr}$ & 0.276 & 0.280 & 0.344 & 0.301 \\
\hline
\end{tabular}

Note: Analyses cited from Baich $^{6}$

\subsection{MRF SB4 Testing Details}

The dry-fed MRF has a cylindrical inner chamber that is approximately 0.5 cubic feet in size, with heating coils winding around the chamber walls. The diameter of the chamber is $\sim 7$ ”, and an insulating sleeve and a $1200 \mathrm{~mL}$ stainless steel beaker (6” deep) were inserted from the top. The tests were conducted with the stainless steel beakers inserted with the sleeve so that the beaker bottom was approximately flush with the top of the uppermost chamber coil. An insulating block was used to cover the beaker. The furnace was heated to $1150^{\circ} \mathrm{C}$ with the top opening covered. Once the furnace reached the setpoint, the cover was removed and the beaker containing sufficient dried, sieved material to produce 525 grams of glass was inserted. After 50 minutes, the beaker was removed from the furnace and allowed to cool to room temperature. This residence time in the furnace was determined during testing in 2002 to establish a standard test time for melt rate comparison for this dry-fed furnace. ${ }^{8}$ After cooling down, the beakers are then sectioned.

The relative melt rate is determined by measuring the height of the glass layer in the bottom of each sectioned beaker at 0.25 ” intervals. The average height and duration in the furnace is used to yield a relative linear melt rate (LMR) number (inches/hour). General observations of the sectioned beaker are also used to describe differences between runs. 


\subsection{RESULTS AND DISCUSSION}

A series of MRF tests were run with simulated SB4 sludge SRAT product and various frits. The following sections give the results of these various tests.

\subsection{Impact of SB4 Washing}

A series of four feeds were made for this test to determine the impact of SB4 sludge washing and the melt rates of SB4 with Frits 418 and 320. The two SB4 sludge washings tested were " 1200 canister baseline" and "1200 canister baseline (one less washed)". SRAT products from the 4-L SRAT runs SB4-3 and SB4-4 were used respectively for the baseline SB4 and one less washed SB4 feeds for these series of tests. Refer to Section 2.0 of this report for further details on these two sludge washings. Table 3-1 summarizes the MRF results. All MRF melt rate data in the document is reported as linear melt rate (LMR - inches/hr).

Table 3-1. MRF Melt Rate (LMR) Results for Impact of SB4 Washing Tests (35\% WL)

\begin{tabular}{||c|c|c|c|c||}
\hline \hline & $\begin{array}{c}\text { BASELINE } \\
\text { SB4/FRIT 418 }\end{array}$ & $\begin{array}{c}\text { 1 LESS WASH } \\
\text { SB4/FRIT 418 }\end{array}$ & $\begin{array}{c}\text { BASELINE } \\
\text { SB4/FRIT 320 }\end{array}$ & $\begin{array}{c}\text { 1 LESS WASH } \\
\text { SB4/FRIT 320 }\end{array}$ \\
\hline *LMR (Inches/Hr) & 0.36 & 0.32 & 0.44 & 0.42 \\
\hline
\end{tabular}

*The range of LMR's for a particular feed run multiple times in the MRF is about 0.02 inches/hr. ${ }^{9}$

The results show that the impact of washing on SB4 was minimal (if any). This was not unexpected due to the similarity (see Table 2-1) of the targeted baseline and one less washed SB4 sludge compositions. In addition, Frit 320 gave higher melt rates than Frit 418 for both sludge washings. Frit 320 has a higher sodium oxide content than Frit 418 (12 versus 8\%) and a lower silica content than Frit 418 (72 versus 76\%). Frit 320 gave higher melt rates as well for the previously run SB3 simulant testing in the SlurryFed Melt Rate Furnace (SMRF). ${ }^{10}$ A series of SB3 MRF tests (with Frits 320 and 418) at various waste loadings was run at the same time as these SB4 tests. At 35\% WL, the SB3/Frit 418 and SB3/Frit 320 feed had linear melt rates of 0.51 and 0.60 inches/hour respectively. With these results, a comparison of SB3 and SB4 (at 35\% WL) with the same frits can be made. The baseline SB4/Frit 418 feed MRF melt rate was about $30 \%$ lower than SB3/Frit 418 feed ( 0.36 versus 0.51 ). The baseline SB4/Frit 320 feed melt rate was about $27 \%$ less than SB3/Frit 320 feed (0.44 versus 0.60$)$. Therefore both frits had about the same percentage drop in melt rate when used with SB4 versus SB3 based on MRF testing.

Currently DWPF is processing SB3 with Frit 418. If Frit 320 is used with SB4, then the loss in melt rate relative to SB3/Frit 418 could possibly be minimized as the SB4/Frit 320 MRF melt rate was only 14\% less than the SB3/Frit 418 melt rate (0.44 versus 0.51$)$. The potential use of Frit 320 with SB4 will be based not only on melt rate assessments, but the robustness to potential compositional variation in the sludge on the projected operational window, potential nepheline formation and the impacts to durability, and sulfate solubility needs.

\subsection{Impact of Sulfate Solubility Frits}

The cited sulfate level for SB4 at the time of testing raised concerns that there could be a glass sulfate solubility issue for SB4 (with either Frit 418 or Frit 320). Therefore a series of frits were designed to increase the sulfate solubility or retention in SB4 glasses. These frits were basically modified versions of Frit 320 in which the silica level was lowered and replaced with $\mathrm{CaO}, \mathrm{V}_{2} \mathrm{O}_{5}$, or a combination of the two oxides (see Lorier at al. $2005^{4}$ for more details).

Given the positive impact on sulfate solubility, the purpose of this series of tests was to determine if SB4 melt rate was negatively impacted by these sulfate solubility frits. Table 3-2 gives the target and 
measured compositions of the four frits tested (Frits 447, 448, 449, and 450) as well as the target Frit 320 for comparison. SRAT product from the 22-L SRAT Run SB4-9 was used for these tests. Further details of the sulfate solubility study for SB4 are given elsewhere. ${ }^{4}$ Table 3-3 gives the MRF melt rates for these frits with SB4 simulant.

Table 3-2. Target and Measured Compositions of SB4 Sulfate Solubility Frits and Frit 320

\begin{tabular}{|c|c|c|c|c|c|}
\hline & FRIT 447 & FRIT 448 & FRIT 449 & FRIT 450 & FRIT 320 \\
\hline $\mathrm{CaO}$ & $(1.92)$ & $(0)$ & $2(1.89)$ & $1(1.03)$ & --- \\
\hline $\mathrm{V}_{2} \mathrm{O}_{5}$ & $0.5 \quad(0.48)$ & $0.5(0.47)$ & $---\quad(0)$ & $---(0)$ & --- \\
\hline $\mathrm{SiO}_{2}$ & $69.5(69.0)$ & 71.5 (72.1) & $70(68.6)$ & $71(70.5)$ & 72 \\
\hline $\mathrm{Li}_{2} \mathrm{O}$ & (8.11) & $\begin{array}{ll}8 & (7.97)\end{array}$ & $\begin{array}{ll}8 & (8.16)\end{array}$ & $8(8.88)$ & 8 \\
\hline $\mathrm{B}_{2} \mathrm{O}_{3}$ & $(7.94)$ & $\begin{array}{ll}8 & (7.71) \\
\end{array}$ & $8 \quad(9.26)$ & $8(7.96)$ & 8 \\
\hline $\mathrm{Na}_{2} \mathrm{O}$ & 12 (12.4) & 12 (12.5) & $12(12.1)$ & $12(11.8)$ & 12 \\
\hline
\end{tabular}

Note: Measured frit compositions are in ( )'s and are averaged normalized values of two analyses. Frit 320 analyses not given as this was not made by ACTL.

Table 3-3. MRF Melt Rates (LMR) for SB4 Sulfate Solubility Frits and Frit 320

\begin{tabular}{||l|c|c|c|c|c||}
\hline \hline & FRIT 447 & FRIT 448 & FRIT 449 & FRIT 450 & FRIT 320 \\
\hline *LMR (Inches/Hr) & 0.40 & 0.43 & 0.47 & 0.40 & 0.44 \\
\hline
\end{tabular}

*The range of LMR for a particular feed run multiple times in the MRF is about 0.02 inches/hr. ${ }^{9}$

Based on the expected range of LMR's for a particular feed, ${ }^{9}$ the sulfate solubility frits for SB4 did not appear to negatively impact melt rate in these MRF tests (as compared to Frit 320). Therefore, the option of using sulfate solubility frits if needed for SB4 appears to be viable.

\section{Impact of Monosodium Titanate (MST)}

There is the possibility that MST from ARP will be added at some point when DWPF is processing SB4. The purpose of these tests was to determine the impact of the MST stream on SB4 melt rate. Two tests were performed with MST added at concentrations to achieve $1 \%$ and $2 \% \mathrm{TiO}_{2}$ in the glass. The $2 \%$ level was chosen as it was cited as the maximum amount that could be added to SB4 sludge and still result in acceptable glass properties, especially with regards to liquidus. ${ }^{11}$ It should be noted that addition of MST not only brings $\mathrm{TiO}_{2}$ to the system but $\mathrm{Na}_{2} \mathrm{O}$ as well. However, $\mathrm{TiO}_{2}$ is present in much greater quantities than $\mathrm{Na}_{2} \mathrm{O}$. Frit 320 was used for these tests at $35 \%$ waste loading. The MST was then added after the SRAT product and the Frit 320 were mixed at 35\% waste loading. Therefore the actual waste loading for these tests was above $35 \%$ as the MST is considered waste. SRAT product from the 22-L SRAT Run SB4-9 was used for these tests.

The $1 \% \mathrm{TiO}_{2}$ feed had an MRF melt rate of 0.40 inches/hr while the $2 \% \mathrm{TiO}_{2}$ feed had a melt rate of 0.74 inches/hr. $\mathrm{TiO}_{2}$, however, should not increase melt rate. In addition, the amount of $\mathrm{Na}$ added from the MST should not have resulted in this high increase in melt rate relative to the Baseline SB4/Frit 320 feed (0.44 inches/hr). Therefore the 1 and $2 \% \mathrm{TiO}_{2}$ tests were rerun. This time the MRF melt rates for the 1 and $2 \% \mathrm{TiO}_{2}$ feeds were similar (0.40 and 0.41 inches/hr for the 1 and $2 \% \mathrm{TiO}_{2}$ feeds respectively). In addition, the first and second runs for the $1 \% \mathrm{TiO}_{2}$ test were similar. Therefore the first $2 \% \mathrm{TiO}_{2} \mathrm{MRF}$ test appears to have been an outlier. Based on the expected range of LMR's for a particular feed, ${ }^{9}$ the results indicate that the addition of the MST stream will not negatively impact SB4 melt rate (when compared to SB4/Frit 320). 


\subsection{Impact of Waste Loading}

A series of MRF tests were run with SB4 SRAT product and Frit 320 at waste loadings from 20 to $43 \%$ to determine the impact of waste loading on SB4 melt rate. SRAT product from the 22-L SRAT Run SB4-9 was used for these tests (except for the 20\% waste loading test which used SB4-12 SRAT Run product). Waste loadings of 20, 25, 28, 32, 37, 40, and 43\% were used. The results of the previously mentioned baseline SB4/Frit 320 MRF test (see Section 3.1) was used for the $35 \%$ waste loading data point. The results of this test series are given in Table 3-4.

Table 3-4. Impact of Waste Loading (WL) on SB4 Baseline MRF Melt Rate (LMR)

\begin{tabular}{||c|c|c|c|c|c|c|c|c|}
\hline WL & $20 \%$ & $25 \%$ & $28 \%$ & $32 \%$ & $35 \%$ & $37 \%$ & $40 \%$ & $43 \%$ \\
\hline *LMR (Inches/Hr) & 0.48 & 0.41 & 0.43 & 0.38 & 0.44 & 0.40 & 0.38 & 0.49 \\
\hline
\end{tabular}

*The range of LMR for a particular feed run multiple times in the MRF is about 0.02 inches/hr. ${ }^{9}$

From past tests, melt rate usually drops as waste loading increases. ${ }^{8,12,13}$ The melt rate was lowered when the waste loading was increased from $20 \%$ to $25 \%$. However, this trend did not continue from $25 \%$ to $40 \%$ waste loading (melt rate about the same with increasing waste loading). The $43 \%$ test appears to be an outlier as the melt rate is the highest of all the waste loadings tested (this has never been observed in the previous MRF tests). The relative insensitivity of the SB4 simulant sludge to changes in waste loading may be due to the high alumina in SB4. The $20 \%$ waste loading test was actually run after the results of the other waste loading tests were determined. This SB4/Frit 320 (20\% waste loading) test was performed to lower the alumina content down near SB3 levels (about 3 percent) for a SB3/Frit 320 melter feed at $35 \%$ waste loading.

\subsection{Impact of Low Lithia Frits}

Melt rate modeling work suggests that lowering the lithia content of the frit could improve melt rate given the negative impact on melt rate of an intermediate Li-Al-silicate phase within the model for SB4. ${ }^{14} \mathrm{~A}$ series of Frit 320 modified frits was designed with lower levels of lithia that were then compensated with higher levels of sodium oxide. The frits made provided acceptable DWPF operating windows when used with SB4 sludge. Table 3-5 gives the target and normalized measured compositions for the four low lithia frits made. SRAT product from the 22-L SRAT Run SB4-12 was used for these tests. Table 3-6 summarizes the MRF melt rate results of these low lithia frit tests. The results of the SB4 low lithia frits tests show that the use of lower lithia frits did not improve melt rate with SB4 when compared to the SB4/Frit 320 (35\% WL) result (0.44 inches/hr) discussed in Section 3.1 of this report. In addition, there was no discernable difference in melt rate for the various low lithia frits with SB4.

Table 3-5. Target and Measured Compositions of Low Lithia Frits and Frit 320

\begin{tabular}{||c|c|c|c|c|c||}
\hline \hline & FRIT 451 & FRIT 452 & FRIT 453 & FRIT 454 & FRIT 320 \\
\hline $\mathrm{B}_{2} \mathrm{O}_{3}$ & $8(7.67)$ & $8(7.72)$ & $8(7.77)$ & $8(7.82)$ & 8 \\
\hline $\mathrm{Li}_{2} \mathrm{O}$ & $6(5.70)$ & $4(3.83)$ & $2(1.98)$ & $5(4.79)$ & 8 \\
\hline $\mathrm{Na}_{2} \mathrm{O}$ & $14(13.73)$ & $16(15.75)$ & $18(18.53)$ & $15(14.72)$ & 12 \\
\hline $\mathrm{SiO}_{2}$ & $72(72.81)$ & $72(72.58)$ & $72(71.57)$ & $72(72.55)$ & 72 \\
\hline
\end{tabular}

Note: Measured frit compositions are in ( )'s and are averaged normalized values of two analyses. 
Table 3-6. MRF Melt Rates (LMR) for Impact of Low Lithia Frits

\begin{tabular}{||c|c|c|c|c||}
\hline & FRIT 451 & FRIT 452 & FRIT 453 & FRIT 454 \\
\hline *LMR (Inches/Hr) & 0.43 & 0.40 & 0.41 & 0.39 \\
\hline
\end{tabular}

*The range of LMR for a particular feed run multiple times in the MRF is about 0.02 inches/hr. ${ }^{9}$

\subsection{Impact of Higher Levels of Sodium in the Sludge}

The projected calcined weight percent sodium in the actual baseline SB4 sludge was 16.2 percent. $^{2}$ Due to the inability to add sodium in the insoluble oxide form to make the SB4 baseline sludge simulant, the targeted calcined weight percent for sodium was $13.7 \%$ (or $18.4 \%$ sodium oxide). The purpose of this set of tests was to add sodium to SRAT product to achieve sodium levels that were 1) the full amount projected for SB4 and 2) halfway between the measured value in the simulated sludge and the full projected value to determine if these higher sodium levels would increase melt rate. Frits 320 and 418 were used in these tests at a targeted waste loading of 35 percent.

Analysis of the sludge used for the 22-L SRAT SB4-12 (SRAT product used for this series of tests) showed that there was 11.2 calcined weight percent sodium (or 15.1\% sodium oxide) in the sludge. Therefore the two targeted sodium values were 16.2\% (full sodium level) and 13.7\% (midpoint between 16.2 and $11.2 \%$ ). The sodium was added to the SRAT product as sodium formate and sodium nitrate in a ratio as to not impact the REDOX of the SRAT product. The results of the MRF tests for this series of tests are given below in Table 3-7. As with most of the other tests, the changes to the feed composition did not have a consistent impact on melt rate. All melt rates were similar to the Frit 418 and Frit 320 SB4 baseline runs discussed in Section 3.1 of this report ( 0.36 and 0.44 inches/hr respectively).

Table 3-7. MRF Melt Rates (LMR) for Higher Levels of Sodium in the SB4 Sludge

\begin{tabular}{||c|c|c|c|c||}
\hline \hline & $\begin{array}{c}\text { FRIT 418 } \\
\text { (FULL NA) }\end{array}$ & $\begin{array}{c}\text { FRIT 418 } \\
\text { (HALF NA) }\end{array}$ & $\begin{array}{c}\text { FRIT 320 } \\
\text { (FULL NA) }\end{array}$ & $\begin{array}{c}\text { FRIT 320 } \\
\text { (HALF NA) }\end{array}$ \\
\hline *LMR (Inches/Hr) & 0.40 & 0.36 & 0.41 & 0.39 \\
\hline
\end{tabular}

*The range of LMR for a particular feed run multiple times in the MRF is about 0.02 inches/hr. ${ }^{9}$ 


\subsection{CONCLUSIONS}

The following conclusions can be made with regards to the initial SB4 MRF melt rate tests:

- $\quad$ Based on the preliminary SB4 composition used, the SB4 sludge melt rate (per dry-fed MRF tests) is lower than SB3 sludge melt rate with the same frit and waste loading. For Frits 418 and 320, simulated SB4 baseline feed melt rate was about 30\% lower than SB3 feed with either of these two frits. However, by using Frit 320 with SB4 baseline sludge at 35\% waste loading, the SB4 feed melt rate was only 14\% less than SB3/Frit 418 feed at 35\% waste loading. SB3/Frit 418 feed is currently being processed at DWPF.

- $\quad$ As with SB3 tests ${ }^{10}$, Frit 320 had a higher relative melt rate than Frit 418 when used with SB4 simulant sludge.

- The impact of washing (baseline vs. one less wash) on melt rate for a given frit was minimal (if any) for the washing scenarios tested. This similarity of these two targeted washed sludge compositions is the reason for this minimal impact.

- Frits designed and demonstrated to increase the sulfate solubility of SB4 glasses did not reduce the melt rate (when compared to SB4/Frit 320). These frits could therefore be considered for use with SB4 or future sludge batches if sulfate solubility limits are exceeded with the current frits (Frits 418 and 320).

- After an initial drop in melt rate when waste loading was increased from $20 \%$ to $25 \%$, melt rate remained fairly constant with increased waste loading (from 25 to 40\%). The $43 \%$ waste loading feed melt rate was higher, but appears to be an outlier as from past tests increased waste loading has not increased melt rate.

- The addition of MST that resulted in increasing the $\mathrm{TiO}_{2}$ levels to 1 and $2 \%$ in the glass did not appear to impact melt rate.

- The theory of using low lithia frits to increase melt rate with the high alumina SB4 sludge was not proven with these MRF tests.

- Increasing the sodium content of the SB4 sludge up to the CBU projected level ${ }^{2}$ to account for insoluble sodium did not increase melt rate.

- With regards to melt rate, SB4 appears to be somewhat resistant to changes in frit composition, waste loading, and additional components such as MST, sludge washing, and additional sodium in the sludge. Nothing has yet been proven as to why this is true, but the best theory for the cause of this as well as the lower melt rate for SB4 (compared to SB3) is the higher alumina amount in SB4.

\subsection{RECOMMENDATIONS/PATH FORWARD}

The following recommendations/path forward are given as a result of the findings of the initial SB4 MRF melt rate tests:

- Confirm findings of SB4 MRF tests with SMRF testing using Frits 418 and 320 using revised SB4 compositions without Tank 4.

- Perform High Temperature X-Ray Diffraction testing (as well as other high temperature analytical tools) to try and determine the cause/solution of the lower melt rate of SB4 (relative to SB3).

- Continue frit development work to increase SB4 melt rate. This could include investigating frits with higher levels of iron or other elements. 


\subsection{REFERENCES}

1. Shah, HB, GR Lilliston, and JM Gilliam. 2005. Preliminary Blending, Washing, Additions, Feed and Glass Qualification Strategies for the Combination of Sludge Batch 4 (Tanks 4, 5, 6, 8, and 11) with Sludge Batch 3 as Feed into DWPF, CBU-PIT-2004-00021, Westinghouse Savannah River Company (WSRC), Aiken, South Carolina.

2. Lilliston, GR. 2005. Development of Elemental Sludge Compositions for Variations of Sludge Batch 4 (SB4), CBU-PIT-2004-00011 (Revision 1), WSRC, Aiken, South Carolina.

3. Peeler, DK and TB Edwards. 2005. A Preliminary Assessment of the Need for a Sludge Batch 4 Variability Study, WSRC-TR-2005-00122, WSRC, Aiken, South Carolina.

4. Lorier, TH, IA Reamer, and RJ Workman. 2005. Initial Sulfate Solubility Study for Sludge Batch 4 (SB4), WSRC-TR-2005-00213, WSRC, Aiken, South Carolina.

5. Smith, ME and DK Peeler. 2004. Task Technical and QA Plan: Investigation to Increase the Overall Waste Throughput in the DWPF Melter, WSRC-RP-2004-00713, WSRC, Aiken, South Carolina.

6. Baich, MA, CC Herman, DR Best, MF Williams, and EK Hansen. 2005. Sludge Batch 4 Initial Simulant Flowsheet Studies: Phase I SRAT Results, WSRC-TR-2005-00194, WSRC, Aiken, South Carolina.

7. Lambert, DP and ME Stone. 2005. Sludge Batch 4 Flowsheet Studies: Preparation of SRAT Product for Dried Feed Melt Rate Furnace Testing and a Comparison of 4-L and 22-L Scale, SRNL-ITS-2005-00163, WSRC, Aiken, South Carolina.

8. Lorier, TH, TM Jones, DC Witt. 2002. Melt Rate Testing for the DWPF: Summary of FY02 Testing, WSRC-TR-2002-00545, WSRC, Aiken, South Carolina.

9. Smith, ME, DH Miller, and TM Jones. 2005. The Impact of the Source of Alkali on Sludge Batch 3 Melt Rate, WSRC-TR-2005-00177, WSRC, Aiken, South Carolina.

10. Smith, ME, DH Miller, and TM Jones. 2004. Slurry-Fed Melt Rate Furnace Test for the SB3/Frit 320 Feed System, WSRC-TR-2004-00459, WSRC, Aiken, South Carolina.

11. Lorier, TH and CM Jantzen. 2003. Evaluation of the $\mathbf{T i O}_{2}$ Limit for DWPF Glass, WSRC-TR2003-00396, WSRC, Aiken, South Carolina.

12. Smith, ME, TH Lorier, and TM Jones. 2003. SMRF and MRF DWPF Melt Rate Tests for SB2/SB3 (Case 6b - 250 Canisters), WSRC-TR-2003-00466, WSRC, Aiken, South Carolina.

13. Lorier, TH and ME Smith. 2004. Melt Rate Assessment of SB2/3 with Frit 418 - Effects of Waste Loading and Acid Addition, WSRC-TR-2004-00098, WSRC, Aiken, South Carolina.

14. Peeler, DK and TB Edwards. 2005. "Low-Li $\mathbf{i}_{2} \mathbf{O}$ ” Frits: Selecting Glasses that Support the Melt Rate Studies and Challenge the Current Durability Model, WSRC-TR-2005-00306, WSRC, Aiken, South Carolina. 


\section{Distribution:}

J. E. Marra, SRNL

R. E. Edwards, SRNL

D. A. Crowley, 999-W

S. L. Marra, 999-W

T. B. Calloway, 999-W

N. E. Bibler, SRNL

C. M. Jantzen, SRNL

J. R. Harbour, 773-42A

C. A. Langton, 773-43A

G. C. Wicks, SRNL

M. E. Smith, 999-W

D. H. Miller, 999-W

T. M. Jones, 999-W

D. K. Peeler, 999-W

C. C. Herman, 773-42A

M. E. Stone, 999-W

T. L. Fellinger, SRNL

A. S. Choi, 773-42A

M. S. Miller, 704-S

A. B. Barnes, 704-30S

J. E. Occhipinti, 704-S

R. M. Hoeppel, 704-27S

J. F. Iaukea, 704-30S

D. C. Iverson, 704-30S

R. J. O’Driscoll, 704-30S

J. W. Ray, 704-S 